\title{
TRIBAL-LED PEOPLE'S RESISTANCE IN TRANSITION: $1765-1800$
}

\author{
Ananda Bhattacharyya \\ West Bengal State Archives
}

The first formidable peasant led Adivasi (Tribal) resistance against the East India Company was the Chuar Rebellion. The Adivasis of the Jungle Mehal (mostly south-west Bengal including a part of Singbhoom, Manbhum, Chtonagpur and a portion of Orissa) were divided into various ethnic groups, viz. Bagdi, Kurmi, Santal, Bhumij, Bauri, Kora, Mahli and Munda and other communities could not tolerate the British policy of resumption of land which they enjoyed since the Mughal period. Besides the lands and their services to the local magnates they had no other means of subsistence. Their grievances coincided with the precarious condition of the zemindars leading to the spark of a popular revolt which is commonly known as Chuar rebellion. The peasants, being oppressed both by the East India Company Officials and local magnates, found no other alternative but to join in the clarion against the colonial regime.

J. C. Price, the Settlement Officer of Midnapore, described the socalled Chuar Rebellion of 1799 the outcome of the "evil passions of the infuriated Sardars and Paiks," which "carried slaughter and flame to very doors of the Magistrate's cutcherry."' The Paiks ('foot-men', being local, hereditary watchmen and militiamen) had been dismissed in large numbers under the British administration established in 1760 and their land grants (paikan) were resumed. What is commonly known as the Chuar rebellion was mainly a revolt of the Paiks and Chuars. The Adivasis living in the jungle mahal were commonly called Chuars since the medieval period as Sri Chaitanya, the Vaishnava apostle of Bengal, passing through the area in 1509 , described these tribal communities as "pirates gathered on the rivers, and robbers on the land."2 A similar perception was found in Kalketu Upakhyan, as Kavikankan Mukundaram Chakraborty called them Chooars. Jogesh Chandra Basu took the Chuar to mean "outlandish fellow,"3 and the name was applied in Midnapore to the wild tribes who inhabited the jungle mehal and the tracts beyond them. The ethnic groups of South-West Bengal, according to the narra-

1 J. C. Price, The Chuar Rebellion of 1799, Calcutta, 1873, 1-3

2 L.S.S. O' Malley Bengal District Gazetteer, Midnapore, Calcutta, 1911, p. 22.

3 Jogesh Chandra Basu, Medinipurer Itihas (in Bengali), Calcutta, 1939 pp. 37-41 A similar account may be found in Tarilokyanath Pal (Medinipur Itihas (in Bengali), Calcutta 1888), pp .75-78 
tives of District Gazetteer, were mainly aborigines composed of Kurmi, Santal, Bhumij, Bauri, Kora, Mahli and Munda and other communities.

The works of Narendra Nath Das ${ }^{4}$ and Binode Sankar Das ${ }^{5}$ contain some information about the Chuars. The Bhumijs, Mundas, and Mankis of Chotonagpur and Sardar Ghatwals formed organized tribal communities and were the main force among of the rebels of jungle mehal. ${ }^{6}$

\section{Different Phases of the Adivasi Resistance}

In 1760 the Company acquired from Mir Qasim, along with Midnapore, the territories of jungle mehals and Dhalbhum. After the grant of Diwani in 1765, the British penetration began in this area when Graham the Resident at Midnapore dispatched a military force to subjugate the jungle zaminders to the west of Midnapore by following "the process of assessing the jungle district to revenue." 7 Fergusson began by attacking and capturing the fort of the chief of Jhargram. ${ }^{8}$ The zamindars of Ramgarh, Samkakulia (Lalgarh), Jambani and Jatbani (Shilda) submitted to the British, who then could push on to Balarampur thana and secure submissions from the chiefs of Amainagar (Ambikanagar), Supur, Manbhum, Chhatna, Barabhum, Rajpur and Phulkusma. ${ }^{9}$

Fergusson was conscious, however, that the tribal chiefs had by no means been thoroughly subdued. Unless a permanent force was established in that area, the collection of the revenue was deemed difficult. ${ }^{10}$ Despite the resistance from the Chuars, there were some zamindars who paid the stipulated revenue to the British authorities. The stronghold of the Chuars lay in Manbhum and Barabhum, particularly in the hills between Ghatsila and Barabhum. They held their lands under a kind of feudal tenure, but were not attached to the soil, being always ready to change the plough for the club, at the bidding of their turbulent jungle chiefs or zamindars who could not be coerced into paying revenue. In a letter from the Collector of Midnapore to Hastings (November, 23, 1781), the rents of the jungle zamindars are described as kind of quit-rent collected from their Paiks and Chuars who are inhabitants of these zamindaris. Several expeditions were sent against them in 1767, 1769

4 Narendra Nath Das, History of Midnapore, (1760-1803), Calcutta, 1956. Two-third portions of the book (in two volumes) contain the narratives of Chuar Rebellion.

5 Binode Sankar Das, Civil Rebellion in the Frontier Bengal, (1760-1805), Calcutta, 1973. He has dealt the Chuar Rebellion in detail throughout the book.

6 Proceddings of Judicial Criminal, dated 27th June, 1796, No. 27, West Bengal State Archives.

7 Graham to Fergusson dated 4 February 1767. This material has been collected from Midnapore District Collectorate (henceforth the source will be referred to as MDC).

8 Fergusson to Graham dated 7 February 1767, No. 120 (MDC).

9 Fergusson to Graham dated 29 February 1767, No. 129 and 6th March 1767, No. 139 (MDC).

10 Fergusson to Graham dated 6 March 1767 (MDC). 
and 1770, but without any substantial success. So a scheme of building small thanas in the interior with 60 sepoys each was put into execution as a means of temporary defence. Later on, in 1795, the landholders of the jungle mehals were vested with the joint charge of police of their respective estates to act in concert with the darogas under Regulation XXII of 1793.

The district records of Manbhum are full of accounts of the Chuar outbreaks in different parts of the country. In $1771 \mathrm{Lt}$. Goodyear and in 1772 Capital Carter, Lt. Gall and Lt. Young were operating in these areas. In 1782 Major Crawford suppressed disturbances in Jhalda and took charge of the collections. He also recommended that the inhabitants of the area formed by the triangle Jhalda, Pachet and Ramgarh be disarmed. Again in 1783-84, disturbances broke-out in Kuliapal, many of these disturbances were related to an increase in taxation.

It was stated that "Barahabhum and other estates which were first assessed got off very lightly, whereas Jhalda, Katras, Jharia, Nawagarh and other estates, which were taken up later on when the British control had been considerably strengthened, had to submit to a comparatively heavy assessment." 11 In this context we should refer the compilation of Walter. K. Firminger. ${ }^{12}$

The surrender of Ghatsila in August 1767 had been preceded by the spontaneous coming together of the zamindars of Patkum and Singhum, and of the Chhatna zamindar. All three were anxious to secure British protection against the attack of their neighbours; indeed, the Chhatna zamindar declared that he would rather "quit the country and starve than become a vassal of Patchet." 13 In mid-1768 trouble was renewed in Ghatsila. Towards the end of 1769 the tribal people, especially Bhumijs, living between the pargana of Dhalbhum and Barabhum were in turmoil and the adivasis of Patchet, Patkum also joined the insurgents. They invaded Ghatsila and forced the Company's sepoys to retire to the Narsinghagarh fort. Subha Singh, the jaigirdar of Koilapal one of the "obstinate" Chuar chiefs, had joined the rebels. He was seized and hanged on the spot as an example for his rebellious mind and mentality. ${ }^{14}$ It appears that the advasis in their initial attempt were not inclined

11 W.K. Firminger (ed.) Midnapore District Records (Letters Issued), Calcutta, 1909, Vol. I, No Manbhum settlement reports, para. 37; J.C. Price, Notes on the History of Midnapore, pp. 67-68, 109, 111, 122; District Gazetteer, Midnapore, p. 38 ff; W.W. Hunter, Bengal MS Records: A Selected List of 14,136 Letters in the Board of Revenue, Calcutta, 17821807, with an historical dissertation and analytical index, London, 1894, Nos. 269, 272, 273 , 403-404, 504, 514, 537, 588, 594, 614-618, 677-678, 713-715, 724.

12 A. Mitra, District Handbook, Midnapore, 1951, Appendix IV, p. xxvi; Graham to Fergusson dated 30 January 1767 (MDC): W.K. Firminger, Midnapore District Records, Vol. I, No. 109.

13 Fergusson to Vansittart 5 June 1767, No. 202 (MDC).

14 Vansittart to Lt. Nun, 8 Janurary 1770, Nos. 509 (MDC). 
to surrender the gun and matchlocks which they seized from the Company's forces. They were undaunted and backed by the sardar of Dhadka, Ghatsila. ${ }^{15}$ It was resolved that "unless Jagannath Dhal was subdued the East India Company could never obtain any revenue from the side of Subarnarekha." 16

Trouble continued in 1770. The Company sent Lt. Goodyear to quell the revolt and he immediately got engaged against various rebels. ${ }^{17}$ With considerable difficulty the rebellion was suppressed at long last in 1773. The British Government being compelled to make peace by restoring the estate of Jagannath, the Raja of Dhalbhum who was the leader of the zamindars.

The disturbances in the western jungles were renewed by Subla Singh and many others including Kuilapal jaghindar, the sardar of Dhadki. They refused to accept the authority of the Company, to settle revenue, and to survey their possessions. The Company mobilised a force of a thousand paiks under Sitaram thanadar. The main object was to reduce them to subjection and to bring them to Midnapore for a speedy and favourable settlement. The uprisings took a serious turn when in February 1773 fresh disturbances broke out in the western jungles under the leadership of Jagannath Dhal of Ghatshila. The ryots of Haldypukur joined with Jagannath and rose in revolt. The paiks of Dompara headed by Mangovin, the zamindar of Silda, were encouraged to commit depredations. ${ }^{18}$ In fact, however, most of the early depredations of the Chuars took place outside the Midnapore district. At this stage Warren Hastings adopted the astute policy of recruiting all able-bodied adult males of this area into the Company's army, keeping them in the Company's pay while recognizing their interest in paikan lands in this territory. These recruits were employed against the Marathas in the First Maratha War.

Much of the Midnapore district was covered with wide stretches of jungles, its inhabitants being mostly Paiks and Chuars, who had the reputation of being careless cultivators but expert in pillage. The hilly and geographical environment of Manbhum helped the insurgents to spread in that region. In the eighteenth and early nineteenth centuries Manbhum was still thickly forested with Sal. Thus, in 1773 it was described as "mountainous and over spread with thick woods, which render it in many places utterly impassable. ${ }^{19}$ In fact, two thirds of Midnapore in the early nineteenth century consisted of jungle, the greater part of which was

15 Eward Baber to Goodyar dated 30 November 1770 Midanpore District Records, Vol. 4. No. 70.

16 Eward Baber to Lt. Goodyar, dated 30 November 1770 (MDC).

17 Capt. J. Forbes from Haldypukur dated 4 April 1773 (MDC).

18 Midnapore Collector to Warren Hastings dated 23 November 1781 (MDC), W.K. Firminger Fifth Reports, p. CXXIX; see also J.C. Price, op. cit., p. 67.

19 Letter to Warren Hastings dated 27 November 1781 (MDC); J.C. Price op. cit., p. 67. 
uninhabited and inaccessible. Bogree, Bishnupur, Pachet, Singhbhum and Mayurbhanj, the main strongholds of the adivasis were surrounded by jungles. The difficulty of realizing revenues from the jungle estates failed very early and it was reported that the adivasis of the jungle mahal areas were "bred up as much for pillaging as cultivating, pay a kind of quit-rent from the profits of both occupations." 20 If we agree with the opinion of Hunter, it can be said that the Permanent Settlement tried to suddenly substitute contract for custom." 21 The tribal cultivators and chiefs had always been guided by their own customs. The new system damaged the interest of both the semi-tribal chiefs and ignorant ryots. Rani Shiromani of the Midnapore estate, the Raja of Pachet, the zamindar of Raipur and several others found themselves driven from pillar to post and they had to face unusual humiliations e.g, arrest, mortgage, sale and attachment of property. According to J.C. Price, the jungle zamindar was a sort of military chief, "to who his ryots might look for protection who might command his paiks with effect, and whose title should not be doubtful." 22 Such doubt was raised out the possession of the zamindari of rani Shiromani, which was caused to be confiscated. The logic of the East India Company behind such acquisition was its bad management and arrears of revenue. She was only entitled to a moshaira. For a time the rebels' sardars wanted to make the Rani their leader but the Rani, though she secretly sympathized with rebels, was not in a position to antagonize the Company's Government. She could not long maintain her neutrality when in the last decade of the eighteenth century the inevitable clash between the Paiks and the Government reached its climax. At the same time the zamindar of Simlapal also encouraged the ryots to rise against the Company. Rani Shiromani was very popular with the dispossessed rebels, Paiks, and the exploited artisans of Anandapur factory. ${ }^{23}$

There was also much public sentiment behind the Rani, as a victimized widow. Her zamindari was let out and brought under Government management. Support for the cause of the Rani constituted a major factor behind the revolt of 1799. In this phase of insurgency the rebels were supported by the peasants who had so long tilled lands for the Paiks without rent, but now they were subjected to the new system of taxation. The situation was aggravated when they suffered from the enhanced prices of salt which coincided with the disbandment of the Paiks. Rani Shiromani also made common cause with Chunilal Khan of Narajol. The situation deteriorated to such a degree that the Government tehsildars

20 A Price, op. cit., p. 73.

21 Hunter, op.cit. Nos.1374, 1489, 1933-35,7890-93,7953.

22 Price, op. Cit, p.70

23 H.V. Bayley, Memoranda of Midnapore, Calcutta, 1902, p. 2. 
could not even collect a rupee from the ryots. ${ }^{24}$ Tribal peasants also were also greatly disturbed by the exit of their old chiefs and the entry of new non-tribal zamindars. There was, therefore, much unrest from 1795 to 1800 in all those estates which were auctioned off for revenue arrears. In the case of Pachet and Raipur, the Government had to yield. In Bishnupur, the Bhumijs of Barabhum, Manbhum and other jungle mahals came in thousands to assist the family of the late Raja Chetan Singh to get back its zamindari. ${ }^{25}$

The unrest began to spread when the Ghatwals began to get aggrieved by the actions of the Government. In 1799 the Midnapore Collector wrote about the ryots that these people "were contented, industrious, brave, truthful, and confiding, much attached too to their proprietors, but if they were oppressed, a whole village would literally in one night 'up stick' and off to some zamindar, whose general character promised them better treatment." 26 The Ghatwals, appearing as the leaders of the tribal community, defied their own chiefs. The Permanent Settlement also damaged the interest of the Ghatwals, so that their custom of receiving 'rewards' was totally curtailed. Their ghatwali (paikan) lands were resumed under the 1793 Regulations. They had thus no alternative but to join with their brethren against the Company's Government.

\section{Trends of Popular Revolt}

The main targets of the rebels' attacks were the tehsildars and serishtadars of Janpur. The tehsildar of Anandpore also reported that it was impossible to realize the revenues and there was a grave risk to his life. The striking feature of the situation was that the police system proved an utter failure. The police darogahs were prone to take bribes and to exploit the simple tribal people at their will. Thus, in 1794 Govind Ram, the police darogah of Chatna and Manbhum, was charged with "having received bribes for releasing persons accused before them." The British Government thought that, the tribals themselves were "in general a very brave and inoffensive people." 27 Under the circumstances it was proposed to frame separate regulations for the jungle zamindars and the ryots in order to realize the revenue. The jungle chiefs or zamindar, however, were deemed a turbulent and independent class, described as follows in 1778: "These zamindars are mere freebooters who plunder their neighbours and one another; and their tenants are banditti, whom

\footnotetext{
24 Revenue Department Proceedings (WBSA)12 April 1799 , no. 45

25 Ibid 15th February, 1799, no. 25.

26 Judicial (Criminal) (WBSA) 22nd February, 1799, no.1.

27 Judicial (Criminal) 22nd February, 1799, no. 1.
} 
they chiefly employ in their outrages. These depredations keep the zamindars and their servants continually in arms." 28

It was suggested that the jungle zamindars outside the area of jungle mahal should be made responsible for the preservation of public peace in their respective estates. Considering the situation, the implementation of a new scheme was deferred until the rebellion had entirely ceased since it was argued that such a concession might create a sense of victory in favour of the Chuars.

The Adivasis adopted guerrilla warfare and avoided any direct clash with the troops, but they hit the sepoys from behind jungle and hill. Many of the sepoys also succumbed to the unwholesome air of the jungles. Written guarantees (muchalaka) were obtained from Raja Gopinath Dhal of Supur, Motilal Dubraj, the eldest son of Raja Jagannath Dhal of Ghatshila, Birchand Hakim, Mukhtar Gopinath, the minor zamindar of Ambikanagar, Pratap Narain, zamindar of Manbhum, Bansi Maiti, mukhtar of Barabhum, and Lachmi Narain, zamindar of Chhatna that they should not assist the Adivasis in any way. Side by side the Board had recommended in September 1799 that for the sake of restoring cultivation, the Paiks might be restored to their former lands and a remission of dues might be allowed. ${ }^{29}$

The loyal zamindars were also entrusted with apprehending the insurgents and it was stated that "any zamindar who may be convicted of having connived at the assemblage or passage of choars" would be punished. Zamindars would also be held responsible for all the property stolen in their jurisdictions. ${ }^{30}$

The Adivasis were encouraged by the zamindars to commit plunder and outrages upon the loyal zamindars. Such plundered booty in addition to revenue on some occasions was distributed among the ryots. These zamindars were considered by the British as 'refractory' and the inhabitants of the territory 'rude and ungovernable.' 31

The rebels did not think it necessary to keep it a secret that their main intension was to burn and plunder the tehsils and zamindaris. Midnapore itself was threatened several times. The situation was so dangerous for the zamindars and European officials that it became quite difficult to travel in the daytime. In 1780, one Rudra Bauri with a hundred of Dhalbhum people plundered the inhabitants of Bishnupur. The Rani of Karnagarh supported the leaders of the disturbance and the Zamindar of Simlapal encouraged the ryots and other villagers of that area to rise up. Raja Jadu Singh was the brain of the insurgents. The powerful servants

28 Revenue Department Proceedings 15th March, 1799, no. 33.

29 Board of Revenue Proceedings, 21st February 1799, No 35

30 Revenue Department Proceedings, 14th September 1799, No. 54

31 Judicial (Criminal) Proceedings, 21 st September 1800, No.23 
of the Rani being dispossessed of their lands, they instigated the paiks to open rebellion. The Rani herself and her attendants took up the leadership of the rebellion together with the other chiefs of the Jungle Mehals. The resistance of the Adivasis became aggressive and formidable after 1794. The Magistrate of Midnapore permitted to distribute the Company's offer of reward for apprehending Lutchmun Singh and others.

In the vicinity of the town of Midnapore there were three places where the Paiks assembled in force, viz. Bahadurpore, Shalbani and Karnagarh, the last place being the residence of the Rani of Midnapore, which had been brought under khas or government management. In these places they started on their various attacks in search of plunder, returning to divide the spoils. In consequence the ryots left their homes and so prevented the collection of revenue. ${ }^{32}$ The former Zamindar of Raipur along with the Paiks and Adivasis surrounded the kutchery of the darogha of Gunada and had fought from evening until 10 o'clock of the following morning. They set fire to the bazaar and kutchery and overran the place and blocked it up. They wounded a sepoy and two of the barkandazes and killed two ryots. The principal leader of the rebels was one Durjan Singh who reputedly had a following of 15,000 men with whom he raided the country. He was once captured, after he had attacked, plundered, and burnt some thirty villages, but when he was put on trial, he had to be released because no one dared to appear against him. His release from jail raised the spirit of the rebels to commit depredation on a wider scale and this in turn compelled the Government to cancel the sale of Pachet and restore the zamindar to his estate. In May 1798, Durjan Singh's followers, a body of 1,500 Chuars, made their appearance in Raipur, set fire to the bazaar and cutchery and raided the countryside.

In July 1798, about 400 adivasis under Gobardhan Dhakpati, a Bagdi leader of pargana Bagri, in Midnapore, appeared in Chndrakona thana. Gobardhan Dhakpati decamped from Daibiha but his wife and daughter were made prisoners. In December the Paiks became so audacious as to take possession of six or seven villages, cutting down the crops, and also plundering fifteen villages taking away their cattle and other effects. The tehsilder of Janpore was unable to collect any revenue from the ryots, who refused to pay unless they were protected. It was feared that the Paiks would take complete possession of the estate. There was trouble also in Basudevpore. The rebels plundered a village and menaced Satpati. A numerous party of Paiks plundered and burnt Rajgarh and were daily committing attacks on Shalbani. The town of Midnapore itself was also threatened. Imhoff, the Collector, wrote to the Magistrate on March 10, 1799, informing him of a report that the Chuars

32 Extract of a letter of Magistrate, Midnapore to the Revenue Board dated September 14th, 1799: Hunter, Bengal MS records, p. 42. 
intended to plunder and burn the town of Midnapore 'either to-night or tomorrow.' 33 On March 14th, the Chuars burned down two villages and, on the next day, government property amounting to 2,000 arras of paddy was consigned to flames in the very large village of Shiromani which was totally sacked. The Chuars raided the zamindari of one Kishen Charan Chatterjee, and plundered the maujas (villages) of Ceamorry, Inaitpur, Ghoshpur, Raghunathpur and Adipur. Madhab Singh, brother of the Raja of Barabhum, at the head of his Chuar followers became so formidable that Wellesley's government had to adopt special measures for his apprehension.

The Paiks had grown so bold that villages not more than one coss from Midnapore were plundered, and the Collector wrote that a few nights earlier about 200 of them with lighted mashals (torches) came to the opposite side of the river Having by Midnapore. They ordered Raghunath Pal, a tehsilder of the lately resumed paikan land, to supply them with a large quantity of rice, dal etc. The ryots were daily streaming into Midnapore with their cattle and effects, while others went to other districts to avoid being plundered. The paddy was not yet cut down, nor did any person dare to cut it down, as they ran the risk of being murdered. When the Collector sent peons, they were generally threatened and manhandled, particularly those whom he sent to demand the balances of Abkari Mahals in the month of Baisakh 1205 (corresponding to 1798-99). The rebels murdered six persons at Shiromani on September 13th; on the 26th two men were put to death near Anandapur; on the 9th October a party of Chuars attacked a village ten miles from Midnapore; and on the 5th and 30th December 1799 they plundered several villages near the town. Durjan Singh, the late zamindar of Raipur, together with a following of 1500 Paiks, attacked some thirty villages, wounded and killed the ryots, plundered their effects and burnt their houses. They also surrounded the houses of the current zamindar's clerk and the daroga ran away. This success so excited the Adivasis that they again with the help of Durjan Singh rose in arms. The zamindar's naib, Kinu Bakhsi, being unable to remain at Raipur for fear of the Paiks, fled to Balarampore. The revenues due from zamindar fell into arrears and part of his estate was ordered to be sold. The Adivasis were so defiant that they appeared in the villages with lighted torches (mashals) and matches and burnt the houses of the officials of the zamindars so that no one dared to harvest the crops. One surbarakar was cut to pieces and another was so beaten that his life was despaired of the Paiks then set fire to the village and all the golahs. The ryots fled to Anandpore where there was once a police outpost, but that place was also threatened. The tehsildars also left their cutchery and 
took refuge in Midnapore. The rebels also made a bonfire at Salbani of the village accounts and took away the property of the deceased Surbarakar Baktaram's house. Amin Ramchandra Chakraborty, who had been deputed to make the jamabandi of Slabani and other villages, was surrounded by about fifty men and threatened with death. No one was willing to take charge of the revenue collection at Bahadurpur. On February 26, 1799 the collector wrote that five villages near Satpati were plundered and burnt and twelve zamindari amlahs (officials) were brutally beaten and burnt to death. The royts, in consequence, fled to the jungles to obtain means of subsistence. The Collector was under the apprehension that the Paiks would succeed in robbing the treasury. They were so bold that in open daylight they hanged suspected persons in the town and plundered their properties. They even threatened to burn the town of Midnapore, so that many of its inhabitants left. The Collector of Midnapore in a letter of March 19, 1799 reported: "I am at a loss to point out the situation of a district Midnapore. I cannot remain an idle spectator of the innumerable outrages which are daily committed with impunity. On the night of the 14th two villages in which there was a quantity of grain were burning during the whole night and part of the next day. . . Bahadurpore also is entirely deserted. . the grain merchants are unable to come to pargana Midnapore to purchase paddy. . . all communications being cut off, the inhabitants are flocking to the town for protection. . and believe that the paiks have determined to plunder and burn." 34

The property of the Government kept in Anandpore village was burnt and plundered by 2000 Paiks. They cut off the heads of one of the Sebandi sepoys and of a barkandaz and hung them up a tree; the rest made their escape to Midnapore. The Collector was alarmed when the Paiks declared their plan to plunder the town of Midnapore. A reward was offered for the arrest of Gobardhan Dagpati and Kanak Singh, "the dangerous men." The police daroga could not obtain any assistance either from Paiks or Digwars, who in fact, threatened death to any of the merchants who should dare to supply the sepoys with provisions, and they declared that they were authorized to do so by the Rani Siromani and the Raja of Karnagarh and Narajole. The peaceful ryots and the zamindars of that locality also joined them.

The Magistrate directed to arrest the Rani, and her adherents and to capture the fort of Karnagarh, a convenient refuge for the insurgents. The Rani asked all the jungle zamindars to meet and decide upon a common course of action. The Paiks spiritedly joined the band of the Adivasis even after the arrest of the Rani and her adherents. The bazaar of Dhalhara was burnt, and a number of cattle carried off. 
In spite of all the measures adopted by the Government, one hundred insurgents attacked the house of Lakshi Charan, Kalicharan Pal, Rupcharan Mahapatra and two chaukidars of Anandapore. Patra, a village of the East Midnapore was set fire to, and Gangaram Mondal who farmed a hudda during the period of decennial settlement, was put to death. Two villages of Silda and Raipur were occupied under a Bagdi leader. They took possession of six or seven villages of Balarampur, Rajgarh, Salbani and Anandapur.

In September 1798 the Adivasis took possession of six or seven villages of Nyabasan and Barjit, refused to pay their revenues to the state treasury, cut down the corps and plundered tehsils' revenue which was ready for dispatch. Thus there were large scale migration of peasantry from the affected villages causing the arrear of revenue and stoppage of cultivation. Some local bandits and robbers took advantage of the situation and tried to create terror in the adjoining areas. Alarmed, the Company's Government installed night patrolling in the streets of Midnapore. Some police officers of Raipur, Silda, Satpati and Manbhum refused to work on the plea of 'indisposition' and so were considered 'delinquents.' Thus the suspicious persons were told to appear at the bungalow of the District Magistrate within fifteen days from the date of publication of a notification.

In considering the nature of rebellion, we have to keep in mind that the main targets of attacks were the loyal zamindars, Tehsildars, grain dealers and the common people. There are some instances where the peasants had become the victims in the hands of the rebels but in most of the cases the peasants had assisted the rebels. ${ }^{35} \mathrm{~A}$ common cause of friendship was established between the peasantry and the Adivasis if any one comes across the thousands of files of West Bengal State Archives and Midnapore District Collectorate. Without the peasant support it was very difficult for the rebels to hide out in the dense forests for a long time. But Ranajit Guha in spite of his attempt to find out the beginning of the peasant insurgency against the colonial Raj had failed to locate such relationships ${ }^{36}$ in the tribal led adivasi resistance and Benay Bhushan Chowdhury ${ }^{37}$ has a casual reference in his work and did not go beyond the explanation already advanced by others. Chowdhury's firm conviction was that "the chuar movements did include a number of tribals who

35 On the basis of the official sources it appears that out of 350 attacks two-third of which with the help of the peasants were directed against the Company, zemindars, tehsildars and other loyal servants of them.

36 Ranajit Guha, Elementary Aspects of Peasants Insurgency in Colonial India, Delhi, 1992.

37 Binay Bhushan Chaudhury, "The Transformation of Rural Protest in Eastern India 1757-1930" Presidential Address delivered in the Indian History Congress Session 1989, pp.503-541. 
had lost their main occupations as agriculturists." It is true that they participated either as recruits of the armies of the local Rajas or other chiefs, or out of motives of gains from plunder and loot, where their means of subsistence were precarious. The threat to burn the town with the help of multi-dimensional components was no doubt an indication of anti-colonial resistance. A phase of the Chuar movement was organized mainly by a group called Paiks who often combined cultivation with their 'police' work for their employers. Quite a number of them had only recently lost their lands and the movement aimed at their restoration.

There is no denying the fact that the resumption of paikan lands was the main reason behind the growth of the rebel's extreme dissatisfaction and that they had no other alternative to "gaining their livelihood than by entering upon a career of rapine and pillage." This explains why the paiks since the beginning of colonial rule were lukewarm in showing their allegiance to the ruling power.

The immediate effect of the Chuar rebellion was that the injudicious system of the management of the paikan lands was postponed. The zamindars of the jungle mehals were armed with police powers, and the inelastic portions of Regulations were not enforced against the defaulting estates. Henry Strachey selected to take charge of the district, while answering to the interrogatories sent by George Dowdeswell, secretary to the government in the judicial department, stated in his letter of January 30, 1802 that two years earlier, the Chuars numbering some thousands burnt and plundered several parganas of Midnapore, but he had adopted the policy of restoring the zamindars to their former estates and securing them in their rights and using their influence and manage their subjects and followers. This policy of investing the zamindars with full authority became the principal means of restoration of tranquillity. Even then, the Chuars were not completely subdued. 